\title{
Insect galls of the Floresta da Cicuta (Volta Redonda, RJ, Brazil)
}

\author{
Ismael Cividini Flor'; Jandira Chachá Ribeiro Flor ${ }^{2}$ \& Paulo Sérgio do Nascimento Furtado ${ }^{3}$
}

\author{
1 Universidade Federal do Rio de Janeiro (UFRJ), Museu Nacional, Departamento de Entomologia. \\ Rio de Janeiro, RJ, Brasil. ORCID: 0000-0002-5173-4210. E-mail: ismaelcflor@gmail.com \\ ${ }^{2}$ Centro Universitário de Barra Mansa (UBM), Curso de Biologia. Barra Mansa, RJ, Brasil. E-mail: jandirachacha@gmail.com \\ ${ }^{3}$ Universidade Federal do Rio de Janeiro (UFRJ), Centro de Educação a Distância do Estado do Rio de Janeiro (CEDERJ), Curso de Biologia. \\ Volta Redonda, RJ, Brasil. E-mail: psnascimentofurtado@gmail.com
}

\begin{abstract}
Insect galls of the Floresta da Cicuta (Volta Redonda, RJ, Brazil). Galls are changes in the pattern of growth and development of plant tissues or organs in response to the action of an inducing organism, usually an insect. The goal of the present study was to inventory the insect galls of the Floresta da Cicuta (Volta Redonda, RJ, Brazil). The collections were carried out along all the trails, totaling 16 hours of sampling. Forty-three morphotypes of insect galls were found in 24 plant species (18 genera and 15 families). Sapindaceae and Euphorbiaceae were the most richness host plant families. Six new records of host plant species are presented: Senefeldera verticillata (Vell.) Croizat. (Euphorbiaceae), Inga acuminata (Fabaceae), Ocotea elegans (Lauraceae), Ouratea stipulata (Ochnaceae), Psychotria nuda (Rubiaceae) and Cestrum intermedium (Solanaceae). Most of the galls occurred on leaves $(n=21)$ and stems $(n=18)$, followed by buds $(n=2)$, two gall morphotypes occurred simultaneously on leaves and stems. One-chambered galls were more frequent $(n=31)$, as well as glabrous galls $(n=33)$. The gallers belong to three insect orders: Diptera (Cecidomyiidae), Hemiptera, and Lepidoptera. The associated fauna comprised parasitoids (Hymenoptera), inquilines (Hemiptera and Coleoptera) and successors (Isoptera and Acari).
\end{abstract}

Key-Words. Galling species; Host plant; Cecidomyiidae.

\section{INTRODUCTION}

Insect galls are pathological structures that originating new formations in the plant tissues, as a result of mechanical and/or chemical stimulation of insects (Bronner, 1992). According to Mani (1964), galls are induced in any part of the plant, both in vegetative organs or reproductive organs, providing food and shelter for the larva until its adult stage. Although the entomogenous galls occur in any part of the plants, they are most common on leaves and branches (Fernandes et al., 1988).

Studies about insect galls and gallers have been performed in different plant species, mainly related to Cecidomyiidae (Diptera), the most important galling taxon. These studies cover aspects such as the description of new species (Maia, 1996a; Maia, 1996b); associations with parasitoids (Maia \& Monteiro, 1999; Maia \& Tavares, 2000); description of developmental stages (Maia, 1993) and patterns that influence the diversity of galls (Fernandes \& Price, 1988; Fernandes et al., 1996; Fernandes et al., 1997a). However, other studies have focused on the description and characterization of galls from different localities (Fernandes et al., 1988; Fernandes et al., 1997b; Maia, 2001; Maia \& Fernandes, 2004; Urso-Guimarães et al., 2003; Urso-Guimarães \& Scareli-Santos, 2006).

The most investigated Brazilian ecosystems in relation to composition of the Cecidomyiidae fauna and diversity of galling insects are the Cerrado and the Atlantic Forest, but these studies still represent a small fraction of the total area of these biomes (Rodrigues et al., 2014).

In the Southeast Region, insect galls inventories were carried out in restinga areas of the states of Espírito Santo (Parque Estadual Paulo César Vinha, Guarapari - Bregonci et al., 2010), São Paulo (Bertioga - Maia et al., 2008) and Rio de Janeiro, Ilha da Marambaia (Mangaratiba - Rodrigues et al., 2014), Marambaia (Maia \& Silva, 2016), Parque Estadual da Costa do Sol Região (Região dos Lagos - Carvalho-Fernandes et al., 2016), and Reserva Particular do Patrimônio Natural Fazenda Caruara (São João da Barra - Carvalho-Fernandes et al., 2016).

The other physiognomies have been under studied as dry seasonal forest (Ilha do Cabo Frio, Arraial do Cabo, RJ - Maia \& Souza, 2013), tableland forest (São Francisco de Itabapoana, RJ - Maia \& Carvalho-Fernandes, 2016), altitudinal fields (Itamonte, MG - Maia, 2014) and ombrophi- 
lous forest (Santa Teresa, ES - Maia et al., 2014), all with a single inventory.

According to IBGE (1992), Floresta da Cicuta is classified as Semidecidual Seasonal Forest. Surveys of galls in this physiognomy are still scarce, according to the literature the following locations were investigated in Brazil: Goiânia, GO - Santos et al., 2010; Ilha do Cabo Frio, Arraial do Cabo, RJ - Maia \& Souza, 2013; Telêmaco Borba, PR - Santos \& Ribeiro, 2015; Maringá, PR - Carvalho et al., 2015; Bodoquena, MS - Urso-Guimarães et al., 2016.

In this context, the goal of the present study was to inventory the insect galls of the Area of Relevant Ecological Interest Floresta da Cicuta (Volta Redonda, RJ), contributing to the knowledge of the gall richness in semidecidual seasonal forest and in the State of Rio de Janeiro.

\section{MATERIAL AND METHODS}

\section{Study area}

The Floresta da Cicuta $\left(22^{\circ} 33^{\prime} 20^{\prime \prime} \mathrm{S}, 44^{\circ} 05^{\prime} 00^{\prime \prime} \mathrm{W}\right)$ covers the municipalities of Volta Redonda and Barra Mansa. It is located in the south region of the State of Rio de Janeiro and has approximately 131,28 ha (Fig. 1A). It is a conservation unity area protected by Decree No. 90792 of January 9, 1985, framing on the Relevant Ecological Interest Area category (ARIE) (IBGE, 1992). According to Costa (2004), the Floresta da Cicuta is the last intact remaining Atlantic Forest in the Paraíba do Sul Valley (Fig. 1B). The climate is mesothermal - Cwa of Koppen with dry winter and hot and rainy summer.
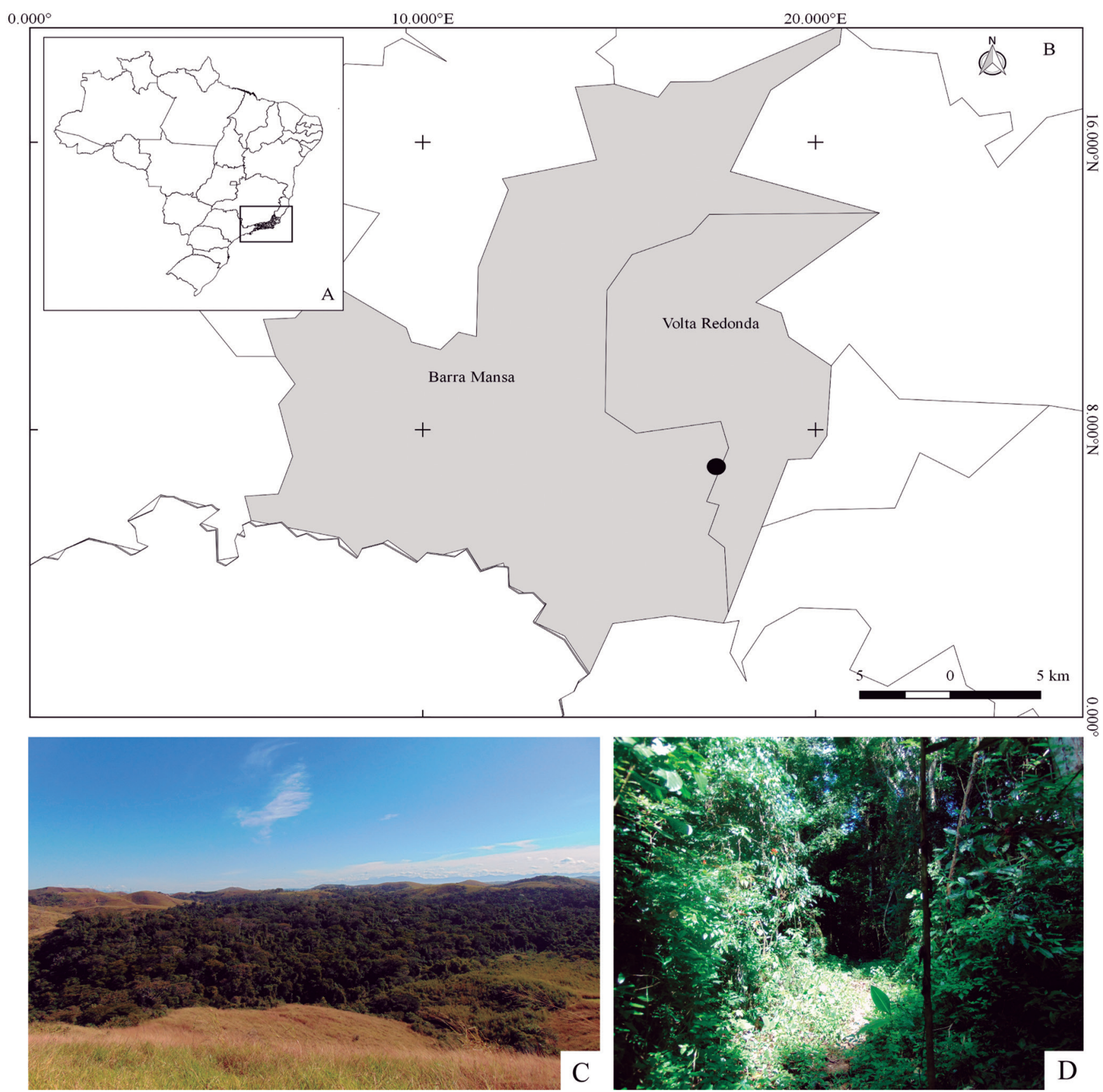

Figure 1. (A-B) Location of the Area of Relevant Ecological Interest Floresta da Cicuta (Volta Redonda, RJ, Brazil). (C) Aerial view of Floresta da Cicuta. (D) View of Trilha Principal where the collection of insect galls were carried out. 


\section{Sampling}

The collections were held in April and June 2015, along the trails: Trilha Principal $\left(22^{\circ} 33^{\prime} 01.01^{\prime \prime} \mathrm{S}, 44^{\circ} 05^{\prime} 23.88^{\prime \prime} \mathrm{W}\right)$, Trilha da Velha $\left(22^{\circ} 33^{\prime} 09.72^{\prime \prime} \mathrm{S}, 44^{\circ} 05^{\prime} 20.03^{\prime \prime} \mathrm{W}\right)$ and Trilha da Figueira $\left(22^{\circ} 32^{\prime} 52.90^{\prime \prime} \mathrm{S}, 44^{\circ} 05^{\prime} 16.61^{\prime \prime} \mathrm{W}\right)$ of the Floresta da Cicuta, totaling 16 hours of sampling (Fig. 1C). All morphotypes were photographed in the field and characterized by shape (Isaias et al., 2013), color, host plant organ, indumentum, grouped or isolated occurrence, and number of internal chambers. Samples of each morphotype were dissected under stereomicroscope for observing the number of internal chambers and obtaining immature insects. Other samples were placed separately in plastic pots, sealed, labeled, lined with moistened paper and inspected daily to check the emergence of adults. All insects obtained were preserved in $70 \%$ alcohol. The cecidomyiids were mounted on microscope slides, following the methodology adopted by Gagné (1994).

Samples of the host plants were pressed and sent to the Jardim Botânico, RJ, experts, to identify at the lowest possible taxonomic level, according to APG III (2009). All botanic names were updated based on the Lista de Espécies da Flora do Brasil (2020), and each species was classified as native or endemic of Brazil based on the same site.

\section{RESULTS}

In the Floresta da Cicuta were found 43 gall morphotypes associated with 24 species of plants, distributed in at least 15 families and 18 genera (Figs. 2-4). The average number of gall morphotypes for host plant species was 1.79. Sapindaceae and Euphorbiaceae presented the greatest number of gall morphotypes (Table 1). The super host genera were Allophylus (with six gall morphotypes) and Croton (with five).

Among the host plants, six are endemic of Brazil: Adenocalymma comosum (Cham.) DC., Senefeldera verticillata (Vell.) Croizat., Ocotea elegans Mez., Ouratea stipulata (Vell.) Sastre, Psychotria nuda (Cham. \& Schltdl.) Wawra, and Meliosma sellowi Urb. The others are native. No exotic host plant species was found in the Floresta da Cicuta. As the gallers are species-specific and monopha- gous, these five morphotypes can be considered as endemic too (Flora do Brasil, 2020).

Most galls were induced on leaves $(n=21)$, stems $(n=18)$, buds $(n=2)$ and two morphotypes occurred both on leaves and stems. Eight different gall shapes were found in this study the most common were fusiform (44\%) and globoid (30\%) (Table 2). The morphotypes were green $(n=21)$, brown $(n=21)$ and white $(n=1)$. In

Table 1. Richness of gall morphotypes by plant families and host plant species in the Area of Relevant Ecological Interest Floresta da Cicuta (Volta Redonda, RJ, Brazil).

\begin{tabular}{lcccc}
\hline \multirow{2}{*}{ Families } & \multicolumn{2}{c}{ Host plant } & \multicolumn{2}{c}{ Galls } \\
\cline { 2 - 5 } & Richness & $\%$ & Richness & $\%$ \\
\hline Asteraceae & 2 & 5.9 & 2 & 4.7 \\
Berberidaceae & 1 & 2.9 & 1 & 2.3 \\
Bignoniaceae & 3 & 8.8 & 3 & 7 \\
Elaeocarpaceae & 2 & 5.9 & 2 & 4.7 \\
Euphorbiaceae & 2 & 5.9 & 5 & 11.6 \\
Fabaceae & 3 & 8.8 & 3 & 7 \\
Lauraceae & 1 & 2.9 & 1 & 2.3 \\
Malvaceae & 2 & 5.9 & 3 & 7 \\
Ochnaceae & 1 & 2.9 & 1 & 2.3 \\
Piperaceae & 1 & 2.9 & 1 & 2.3 \\
Proteaceae & 1 & 2.9 & 1 & 2.3 \\
Rubiaceae & 1 & 2.9 & 1 & 2.3 \\
Sabiaceae & 1 & 2.9 & 1 & 2.3 \\
Sapindaceae & 1 & 2.9 & 6 & 14 \\
Solanaceae & 2 & 5.9 & 2 & 4.7 \\
Not determined & 10 & 29.4 & 10 & 23.3 \\
\hline Total & 34 & 100 & 43 & 100 \\
\hline & & & & \\
\hline
\end{tabular}

Table 2. Number of gall morphotypes of different shapes in the Area of Relevant Ecological Interest Floresta da Cicuta (Volta Redonda, RJ, Brazil).

\begin{tabular}{lcc}
\hline \multicolumn{1}{c}{ Shapes } & Number of gall morphotypes & $\%$ \\
\hline Fusiform & 19 & 44 \\
Globoid & 13 & 30 \\
Midvein swelling & 3 & 7 \\
Discoid & 3 & 7 \\
Conical & 2 & 5 \\
Spheroid & 1 & 2 \\
Leaf roll & 1 & 2 \\
Circular & 1 & 2 \\
\hline
\end{tabular}

Table 3. Arthropod fauna associated with insect galls in the Area of Relevant Ecological Interest Floresta da Cicuta (Volta Redonda, RJ, Brazil).

\begin{tabular}{|c|c|c|c|}
\hline Host Plant & Gall morphotype & Associated fauna & Guild \\
\hline Adenocalymma comosum & Leaf/stem gall, fusiform, brown, glabrous and one-chambered & Acari & Successor \\
\hline Bignoniaceae & Stem gall, fusiform, brown, glabrous and multi-chambered & Hymenoptera & Parasitoid \\
\hline Croton sp. & Leaf gall, globoid, green, glabrous and one-chambered & Hymenoptera & Parasitoid \\
\hline \multirow[t]{3}{*}{ Allophylus edulis } & Stem gall, fusiform, brown, hairy and one-chambered & Pteromalidae, Hymenoptera & Parasitoid \\
\hline & Stem gall, fusiform, green, glabrous and one-chambered & Hymenoptera & Parasitoid \\
\hline & Stem gall, globoid, brown, hairy and multi-chambered & Hymenoptera & Parasitoid \\
\hline Cestrum sp. & Stem gall, globoid, green, glabrous and multi-chambered & Hymenoptera & Parasitoid \\
\hline Senefeldera verticillata & Leaf gall, globoid, green, glabrous and one-chambered & Isoptera & Successor \\
\hline Not identified & Leaf gall, midvein swelling, green, glabrous and one-chambered & Hemiptera & Inquiline \\
\hline Not identified & Stem gall, fusiform, brown, glabrous and multi-chambered & Coleoptera & Inquiline \\
\hline Not identified & Leaf gall, globoid, green, hairy and one-chambered & Hymenoptera & Parasitoid \\
\hline
\end{tabular}


relation to the indumentum and internal chambers, most galls were glabrous $(n=33)$ and one-chambered $(n=31)$.

The gallers of ten morphotypes were determined. They belong to three insect orders: Diptera (Cecidomyiidae), Hemiptera, and Lepidoptera. The former mentioned was the most frequent galling taxa, being responsible for eight morphotypes, followed by Hemiptera, and Lepidoptera both with one. The gallers of 33 morphotypes cannot be determined, because the galls were already empty when collected or occupied by two or more different dwellers and their food habit could not be determined. Three galling insects were identified at tribe level: Lopesiini sp.1 (Diptera, Cecidomyiidae) on Bignoniaceae, Lopesiini sp.2 on Guazuma ulmifolia Lam. (Malvaceae) and Alycaulini sp. on an undetermined host plant species.
A

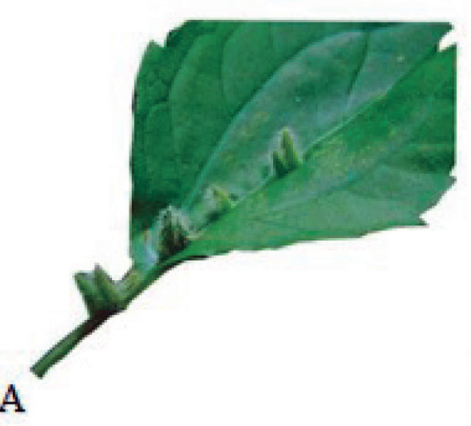

B

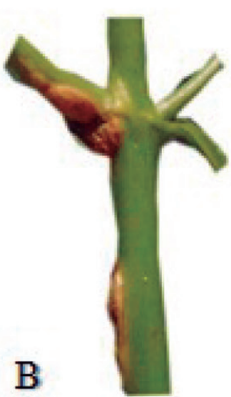

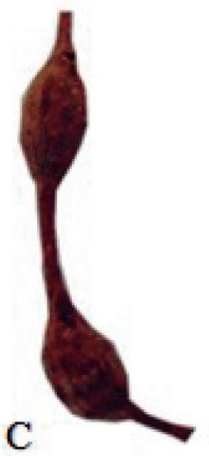

C

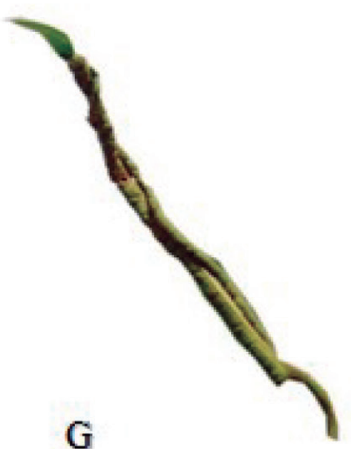

D

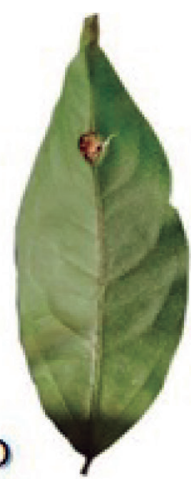

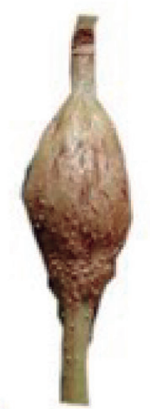

E

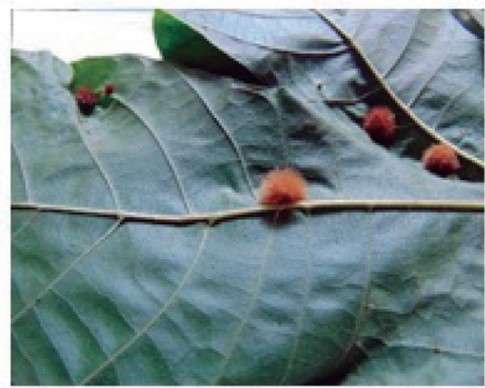

F
G

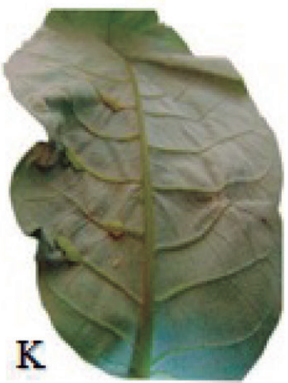

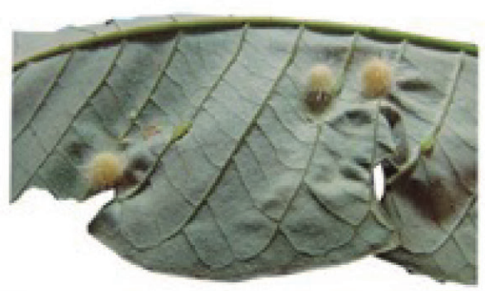

J

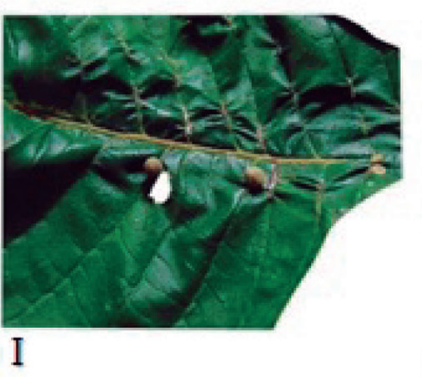

I
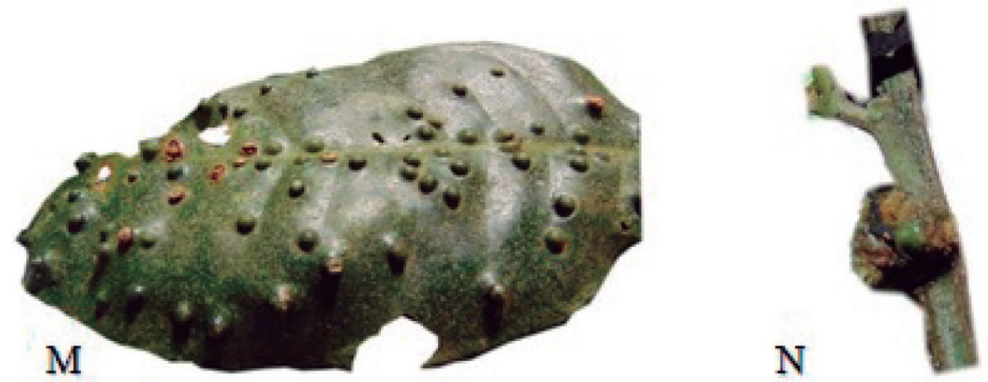

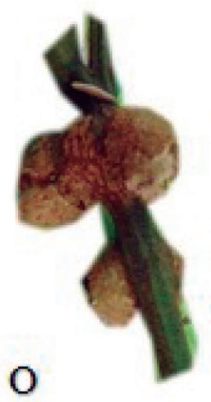

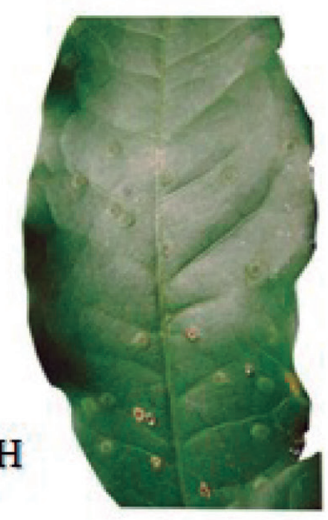

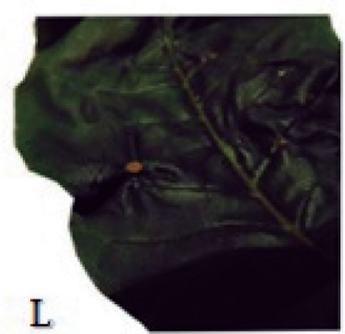

\section{L}

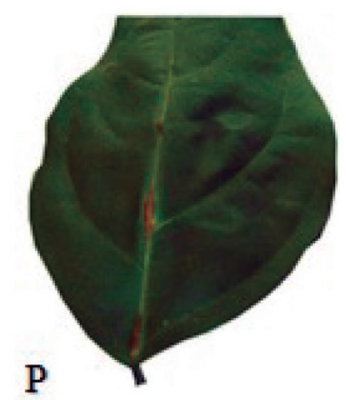

Figure 2. Insect galls of the Area of Relevant Ecological Interest Floresta da Cicuta (Volta Redonda, RJ, Brazil). (A-B) Asteraceae: (A) Chromolaena sp., leaf gall, (B) Vernonia sp., stem gall, (C) Berberidaceae: Berberis sp., stem gall. (D-F) Bignoniaceae: (D) Adenocalymma comosum, leaf/stem gall, (E) sp.1, stem gall, (F) sp.2, leaf gall. (G-H) Elaeocarpaceae: Sloanea guianensis, (G) leaf roll gall, (H) leaf parenchymal gall. (I-M) Euphorbiaceae: Croton sp. (I) leaf gall, (J) leaf gall, (K) leaf gall (L) leaf gall, (M) Senefeldera verticillata, leaf gall. Fabaceae: (N) Inga acuminate, bud gall, (0) Mimosa sp., stem gall, (P) sp.1, leaf gall. 
The associated fauna comprised parasitoids, inquilines and successors. This fauna was found in seven, two and two of galls morphotypes, respectively. Parasitoids, represented by Hymenoptera, were found in galls on Bignoniaceae, Euphorbiaceae, Sapindaceae, Solanaceae and an unidentified plant. Inquilines represented by Hemiptera and Coleoptera, were obtained from galls on two unidentified plants. Successors represented by Isoptera and mites (Acari) were observed on Senefeldera verticillata (Euphorbiaceae) and Bignoniaceae, respectively. This is the first record of Isoptera as successors in insect galls (Table 3).

Data on insect galls are presented here under host plant families, genera and species in alphabetical order. They include gall morphological characterization, associated fauna and previous records in Brazil.

\section{Asteraceae}

\section{Chromolaena sp. (native genus)}

Leaf gall, conical, green, hairy and one-chambered (Fig. 2A).

Previous records: Galls on Chromolaena spp. were recorded in Pará.

Galler: Clinodiplosis eupatorii Felt, 1911 (Toma \& Maia, 2012).

\section{Vernonia sp. (native genus)}

Stem gall, fusiform, brown, glabrous and one-chambered (Fig. 2B).

Previous records: Galls on Vernonia spp. were recorded in Rio Grande do Sul state (Mendonça et al., 2014), Bertioga (SP) (Maia et al., 2008), Carapebus and Jurubatiba (RJ) (Monteiro et al., 2004), Belo Horizonte (MG) (Fernandes et al., 1988), Santa Teresa, (ES) (Maia et al., 2014), Serra de São José (MG) (Maia \& Fernandes, 2004), Tiradentes (MG) (Maia, 2014), Vale do Jequitinhonha (MG) (Fernandes et al., 1997b).

\section{Berberidaceae}

\section{Berberis sp.}

Stem gall, fusiform, brown, glabrous and one-chambered (Fig. 2C).

Previous records: Galls on Berberis spp. were recorded in Rio Grande do Sul state (Mendonça et al., 2014).

\section{Bignoniaceae}

\section{Adenocalymma comosum (Cham.) DC. (endemic species)}

Leaf/stem gall, fusiform, brown, glabrous and one-chambered (Fig. 2D).
Previous records: Galls on A. comosum were recorded in Ilha da Marambaia (RJ) (Rodrigues et al., 2014).

Associated fauna: Acari (successor).

\section{Bignoniaceae sp.1}

Stem gall, fusiform, brown, glabrous and multi-chambered (Fig. 2E).

Associated fauna: Hymenoptera (parasitoid).

\section{Bignoniaceae sp.2}

Leaf gall, globoid, brown, hairy and one-chambered (Fig. 2F).

Galler: Lopesiini (Cecidomyiidae).

\section{Elaeocarpaceae}

\section{Sloanea guianensis (Aubl.) Benth.}

Leaf gall, roll, green, glabrous, and multi-chambered (Fig. 2G).

Previous records: The same gall has been recorded in Bertioga (SP) (Maia et al., 2008).

Galler: Clinodiplosis sp. (Cecidomyiidae).

Leaf gall, discoid, green, glabrous and one-chambered (Fig. $2 \mathrm{H}$ ).

Previous records: The same gall has been recorded in Bertioga (SP) (Maia et al., 2008).

Galler: Lasiopteridi (Cecidomyiidae).

\section{Euphorbiaceae}

\section{Croton sp.}

Leaf gall, globoid, green, glabrous and one-chambered (Fig. 2l).

Galler: Cecidomyiidae.

Associated fauna: Hymenoptera (parasitoid).

Leaf gall, spheroid, white, hairy and one-chambered (Fig. 2J).

Galler: Cecidomyiidae.

Previous records: The same gall has been recorded on Croton floribundus in Tiradentes (MG) (Maia \& Fernandes, 2004).

Galler: Clinodiplosis sp. (Cecidomyiidae).

Associated fauna: Hymenoptera (parasitoid) and Lepidoptera (inquilinous).

Leaf gall, midvein swelling, green, glabrous and one-chambered (Fig. 2K).

Previous records: The same gall has been recorded on Croton floribundus in Tiradentes (MG) (Maia \& Fernandes, 2004).

Galler: Lasiopteridi (Cecidomyiidae).

Associated fauna: Hymenoptera (parasitoid). 
Leaf gall, circular, green glabrous and one-chambered (Fig. 2L).

Previous records: Galls on Croton spp. were recorded in Ilha da Marambaia (RJ) (Rodrigues et al., 2014), Pará (Almada \& Fernandes, 2011), Catimbau Valley National Park (PE) (Silva et al., 2011), Tiradentes (MG) (Maia \& Fernandes, 2004). Maia \& Fernandes (2004) compiled the records of galls for five host plant species, four galls induced by cecidomiids and one induced by Eriophyidae (Acari), found by other authors for the genus Croton (Gagné, 1994; Rübsaamen, 1905; Tavares, 1922; Houard, 1933; Tavares, 1925; Tavares, 1915).

\section{Senefeldera verticillata (Vell.) \\ Croizat. (endemic species)}

Leaf gall, globoid, green, glabrous and one-chambered (Fig. 2M). This is the first record of gall on S. verticillata.

Associated fauna: Isoptera (successors). This is the first record of Isoptera as successors in insect galls.

\section{Fabaceae}

\section{Inga acuminata Benth.}

Bud gall, globoid, green, hairy and one-chambered (Fig. $2 \mathrm{~N}$ ). This is the first record of gall on I. acuminata.

\section{Mimosa sp.}

Stem gall, globoid, brown, glabrous and one-chambered (Fig. 2O).

Galler: Lepidoptera.

Previous records: Galls on Mimosa spp. were recorded in Caetité (BA) (Nogueira et al., 2016), Paramirim (PE) (Maia et al., 2010), Xingó (Northeast region) (CarvalhoFernandes et al., 2012), Ceará (Gagné \& Jaschhof, 2014), Rio Grande do Sul (Mendonça et al., 2014), Grumari (RJ) (Oliveira \& Maia, 2005).

\section{Fabaceae sp.1}

Leaf gall, fusiform, brown, glabrous and one-chambered (Fig. 2P).

\section{Lauraceae}

\section{Ocotea elegans Mez. (endemic species)}

Stem gall, fusiform, brown, glabrous and multi-chambered (Fig. 3A). This is the first record of gall on O. elegans.

\section{Malvaceae}

\section{Guazuma ulmifolia Lam.}

Stem gall, fusiform, green, hairy and one-chambered (Fig. 3B).
Leaf gall, globoid, green, hairy and one-chambered. Galler: Lopesiini (Cecidomyiidae) (Fig. 3C).

Previous records: Galls on G. ulmifolia were recorded in Serra do Cipó (MG) (Coelho et al., 2009).

\section{Guazuma sp.}

Leaf gall, conical, green, glabrous and one-chambered (Fig. 3D).

Galler: Hemiptera.

\section{Ochnaceae}

\section{Ouratea stipulata (Vell.) Engl. (endemic species)}

Leaf gall, discoid, green, glabrous and one-chambered (Fig. 3E). This is the first record of gall on O. stipulata.

\section{Piperaceae}

\section{Piper amalago L.}

Leaf gall, discoid, green, glabrous and one-chambered (Fig. 3F).

Previous records: Galls on P. amalago were recorded in Grumari (RJ) (Oliveira \& Maia, 2005).

\section{Proteaceae}

\section{Roupala montana var. brasiliensis (Klotzsch) K.S. Edwards}

Leaf/stem gall, globoid, brown, glabrous and one-chambered (Fig. 3G).

Galler: Cecidomyiidae.

Previous records: Galls on $R$. montana were recorded in Caldas Novas (GO) (Santos et al., 2012), Ecological Station of Jataí (SP) (Saito \& Urso-Guimarães, 2012), Serra dos Pireneus (GO) (Araújo et al., 2011), Rio Grande do Sul (Toma \& Mendonça, 2013).

\section{Rubiaceae}

\section{Psychotria nuda (Cham. \& Schltdl.) Wawra (endemic species)}

Leaf gall, globoid, brown, hairy and one-chambered (Fig. $3 \mathrm{H}$ ). This is the first record of gall on P. nuda.

\section{Sabiaceae}

\section{Meliosma sellowii Urb. (endemic species)}

Stem gall, fusiform, brown, glabrous and multi-chambered (Fig. 3I). This is the first record of gall on M. sellowii. 


\section{Sapindaceae}

\section{Allophylus edulis (A. St.-Hil. et al.) Hieron. ex Niederl.}

Stem gall, fusiform, brown, hairy and one-chambered (Fig. 3J).

Associated fauna: Pteromalidae (Hymenoptera) (parasitoid).
Leaf gall, midvein swelling, green, glabrous and one-chambered (Fig. 3K).

Stem gall, globoid, brown, glabrous and multi-chambered (Fig. 3L).

Stem gall, fusiform, green, glabrous and one-chambered (Fig. 3M).

Associated fauna: Hymenoptera (parasitoid).
A

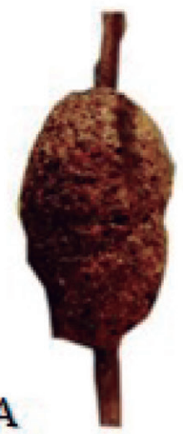

B
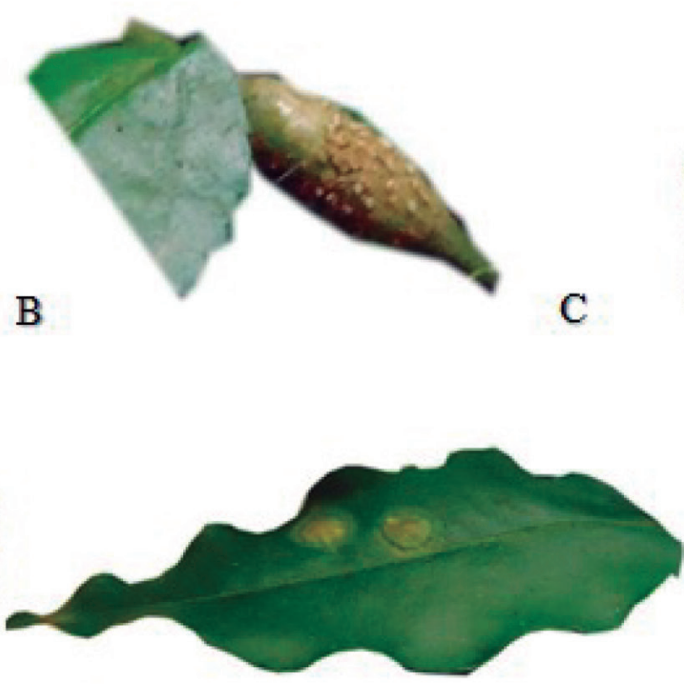

$\mathrm{E}$

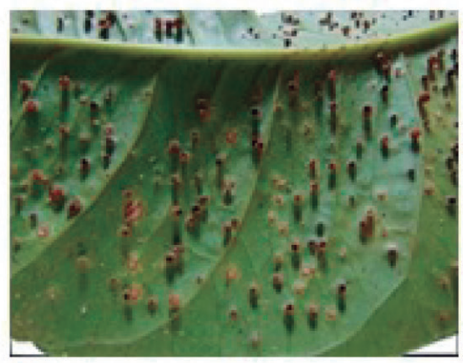

$\mathrm{H}$

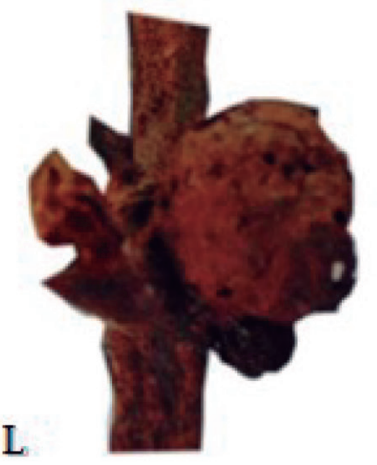

M
C

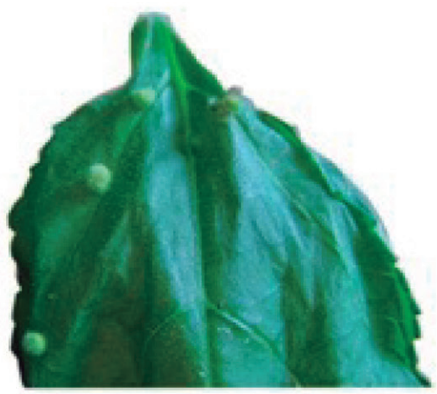

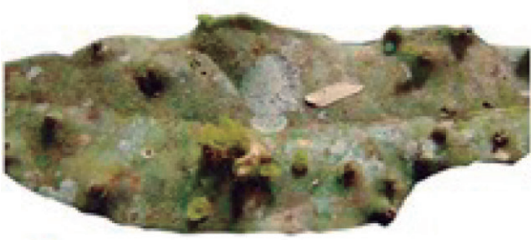

D

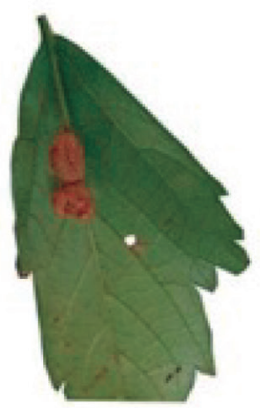

G

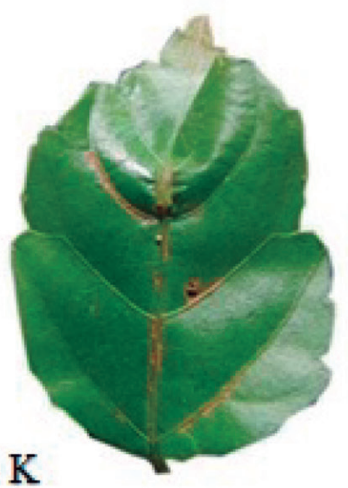

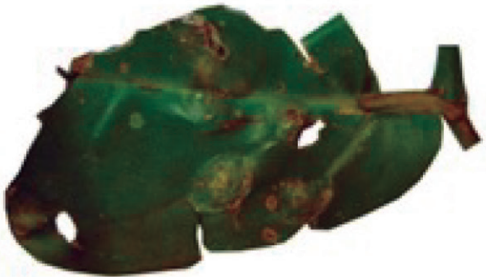

F

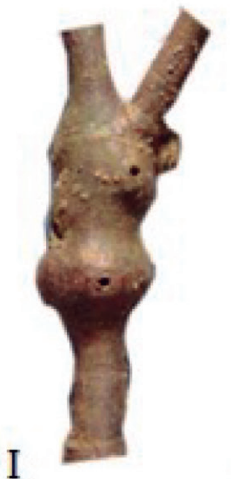

J
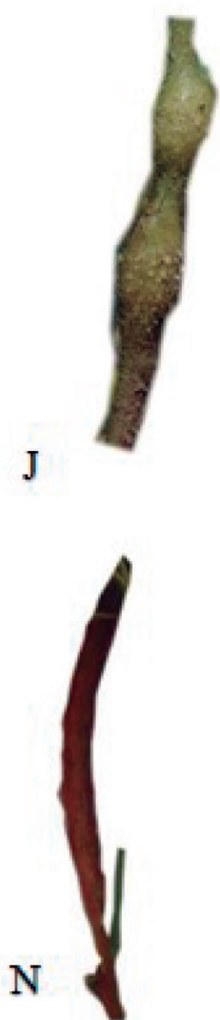

Figure 3. Insect galls of the Area of Relevant Ecological Interest Floresta da Cicuta (Volta Redonda, RJ, Brazil). (A) Lauraceae: Ocotea elegans, stem gall. (B-D) Malvaceae: Guazuma ulmifolia, (B) stem gall, (C) leaf gall, (D) Guazuma sp., leaf gall. (E) Ochnaceae: Ouratea stipulata, leaf gall. (F) Piperaceae: Piper amalago, leaf gall. (G) Proteaceae: Roupala montana var. brasiliensis, leaf/stem gall. (H) Rubiaceae: Psychotria nuda, leaf gall. (I) Sabiaceae: Meliosma sellowii, stem gall. (J-N) Sapindaceae: Allophylus edulis (J) stem gall, (K) leaf gall, (L) stem gall, (M) stem gall, (N) stem gall. 

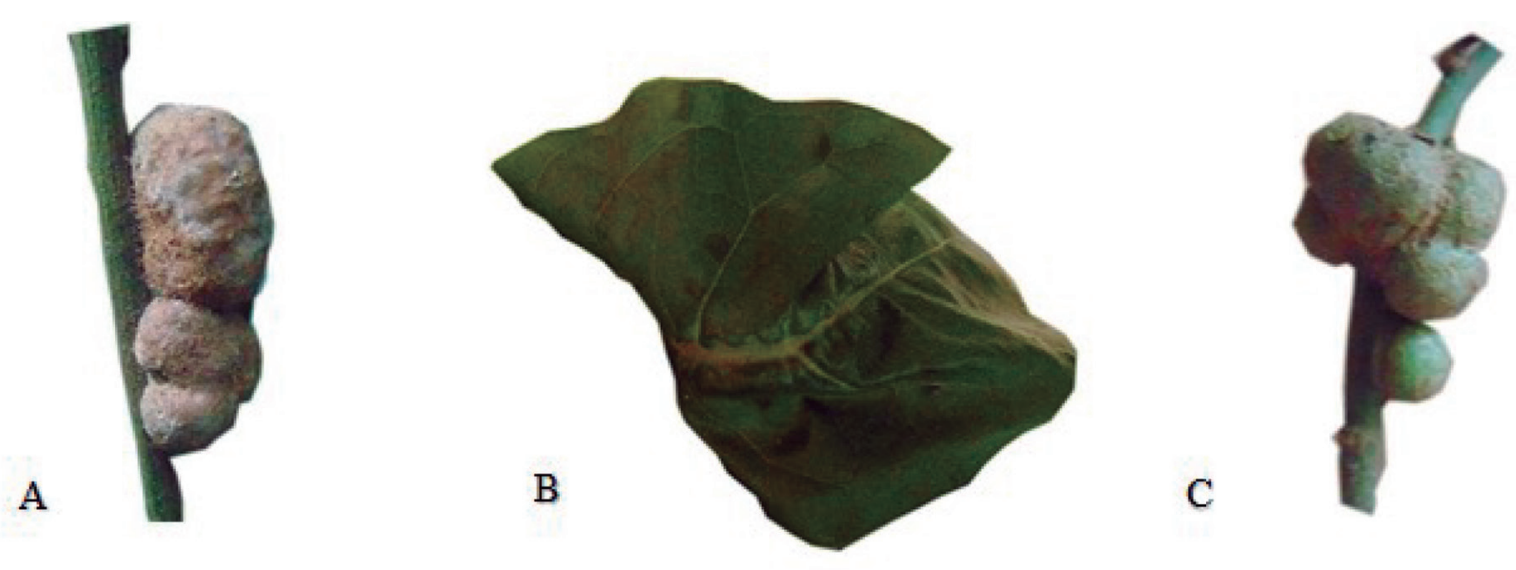

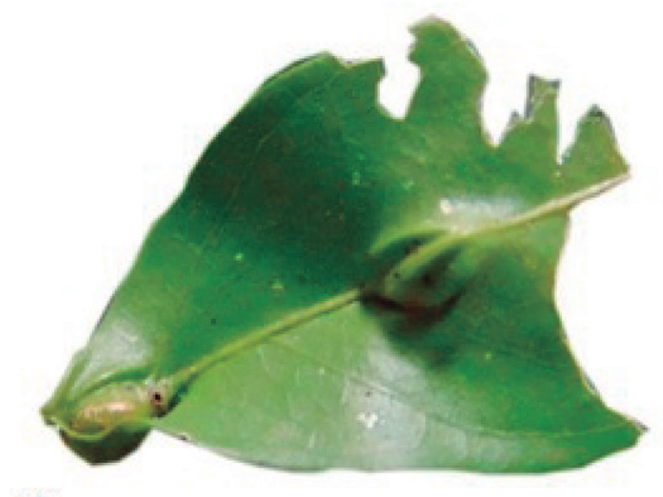

$\mathrm{D}$

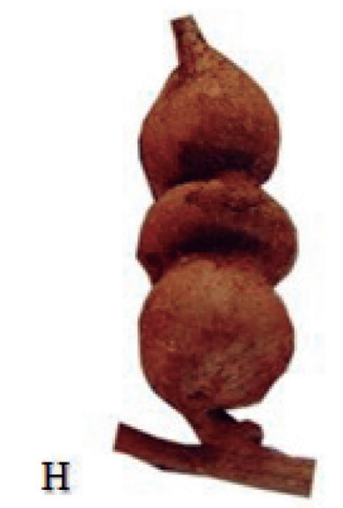

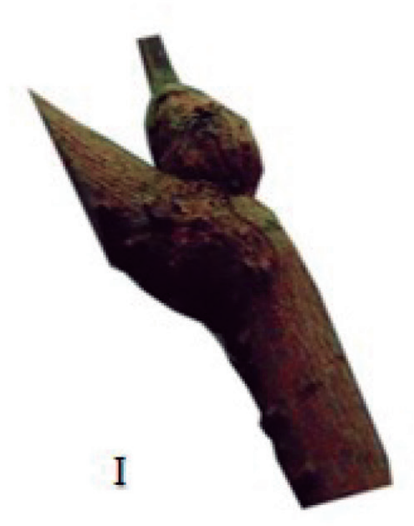

F
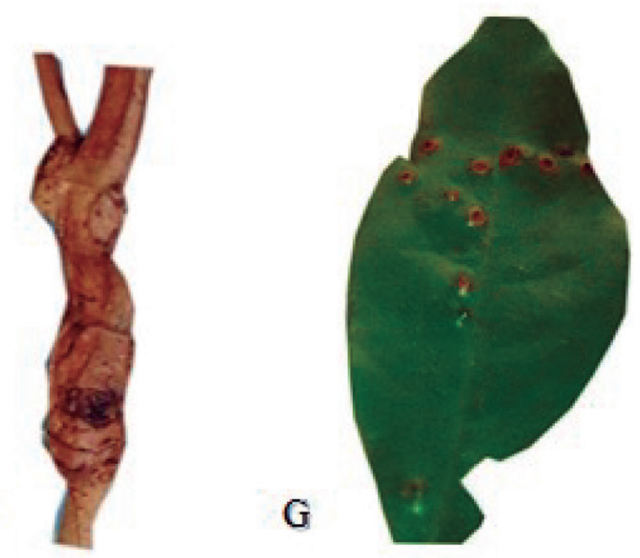
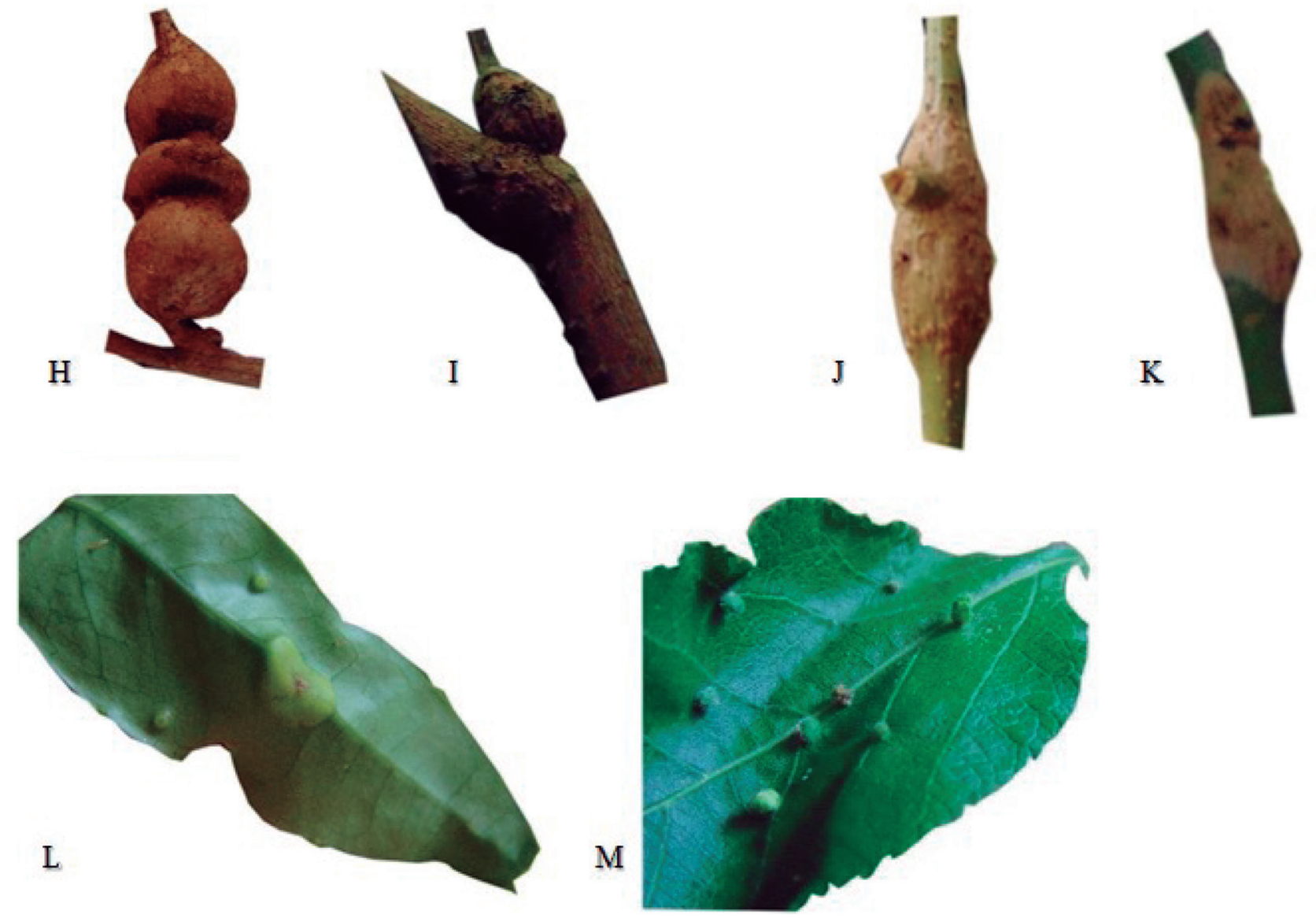

Figure 4. Insect galls of the Area of Relevant Ecological Interest Floresta da Cicuta (Volta Redonda, RJ, Brazil). (A) Sapindaceae: Allophylus edulis, stem gall. Solanaceae: (B) Cestrum intermedium, leaf gall. (C) Cestrum sp., stem gall. (D-M) Not identified: (D) leaf gall, (E) stem gall, (F) stem gall, (G) leaf gall, (H) stem gall, (I) bud gall, (J) stem gall, (K) stem gall, (L) leaf gall (M) leaf gall. 
Stem gall, fusiform, brown, glabrous and multi-chambered (Fig. 3N).

Stem gall, globoid, brown, hairy and multi-chambered (Fig. 4A).

Associated fauna: Hymenoptera (parasitoid).

Previous records: Galls on $A$. edulis were recorded in São Francisco de Paula (RS) - Araucaria Forest (Toma \& Mendonça, 2013).

\section{Solanaceae}

\section{Cestrum intermedium Sendtn.}

Leaf gall, fusiform, green, glabrous and one-chambered (Fig. 4B).

\section{Cestrum sp.}

Stem gall, globoid, green, glabrous and multi-chambered (Fig. 4C).

Associated fauna: Hymenoptera (parasitoid).

Previous records: Galls on Cestrum were recorded in Bertioga (SP) (Maia et al., 2008), Santa Teresa, (ES) (Maia et al., 2014), Mato Grosso do Sul (Urso-Guimarães et al., 2016). Maia et al. (2008) compiled the records of galls for four host plant species, three galls induced by Aphidae (Hemiptera) and one induced by cecidomyiidae (Diptera), found by other authors for the genus Cestrum (Tavares, 1909; Tavares, 1915; Houard, 1933).

\section{Not identified}

Leaf gall, midvein swelling, green, glabrous and one-chambered (Fig. 4D).

Galler: Alycaulini (Cecidomyiidae).

Associated fauna: Hemiptera (inquiline).

Stem gall, fusiform, brown, glabrous and multi-chambered (Fig. 4E).

Stem gall, fusiform, brown, glabrous and multi-chambered (Fig. 4F).

Leaf gall, globoid, green, glabrous and one-chambered (Fig. 4G).
Stem gall, fusiform, brown, glabrous and multi-chambered (Fig. 4H).

Galler: Cecidomyiidae.

Associated fauna: Coleoptera (inquiline).

Bud gall, fusiform, brown, glabrous and one-chambered (Fig. 4I).

Stem gall, fusiform, brown, glabrous and one-chambered (Fig. 4J).

Stem gall, fusiform, brown, glabrous and multi-chambered (Fig. 4K).

Leaf gall, fusiform, green, glabrous and one-chambered (Fig. 4L).

Leaf gall, globoid, green, hairy and one-chambered (Fig. 4M).

Associated fauna: Hymenoptera (parasitoid).

\section{DISCUSSION}

The gall richness values found in the present study are similar for some studies performed in the Semidecidual Seasonal Forest, for example in Telêmaco Borba, PR (Santos \& Ribeiro, 2015) and Ilha do Cabo Frio, Arraial do Cabo, RJ (Maia \& Souza, 2013), lower values were recorded in Goiânia, GO (Santos et al., 2010), and Maringá, PR (Carvalho et al., 2015). Urso-Guimarães et al. (2016) with 65 morphotypes recorded the greatest richness of galls for this physiognomy. However, it is worth mentioning that the sample effort in the different works cited was not performed in the same way thus hindering the direct comparison of the results (Table 4). The average number of gall morphotypes for host plant species was 1.79 . In Brazilian inventories, the average ranges from 1.0 to 2.1 (Maia et al., 2014). Similar values were found for all other areas already studied in the Semideciduous Seasonal Forest (Santos et al., 2010; Maia \& Souza, 2013; Carvalho et al., 2015; Santos \& Ribeiro, 2015; Urso-Guimarães et al., 2016). This fact is interesting, because suggest a limitation in the number of galling species supported by host plant species (Maia \& Oliveira, 2010).

Sapindaceae and Euphorbiaceae were the families with the highest number of galls. In the Brazil, some studies also recorded these families as the richest in insect galls (Santos \& Ribeiro, 2015; Carvalho et al., 2015

Table 4. Data from literature on insect gall inventories in Semidecidual Seasonal Forest of Brazil (Goiânia, GO - Santos et al., 2010; Ilha do Cabo Frio, Arraial do Cabo, RJ - Maia \& Souza, 2013; Telêmaco Borba, PR - Santos \& Ribeiro, 2015; Maringá, PR - Carvalho et al., 2015; Bodoquena, MS - Urso-Guimarães et al., 2016).

\begin{tabular}{|c|c|c|c|c|c|c|}
\hline & Cicuta & Bodoquena & Telêmaco Borba & Goiânia & Cabo Frio & Maringá \\
\hline Number of morphotypes & 43 & 65 & 41 & 34 & 45 & 35 \\
\hline Number of host plant species & 24 & 38 & 32 & 20 & 29 & - \\
\hline Average number of morphotypes/host plant species & 1.79 & 1.71 & 1.28 & 1.7 & 1.55 & - \\
\hline Sampling effort & $16 \mathrm{hs}$ & $8 \mathrm{hs}$ & $10 \mathrm{hs}: 30 \mathrm{~min}$ & - & $24 \mathrm{hs}$ & Plots \\
\hline \multirow[t]{3}{*}{ Richest plant families } & Euphorbiaceae & Bignoniaceae & Asteraceae & Leguminosae & Asteraceae & Sapindaceae \\
\hline & Sapindaceae & Asteraceae & Euphorbiaceae & Styracaceae & Myrtaceae & - \\
\hline & - & Rubiaceae & Solanaceae & Ulmaceae & - & - \\
\hline \multirow[t]{3}{*}{ Super-host plant genera } & Allophylus & Fridericia & Croton & Bauhinia & Eugenia & - \\
\hline & Croton & Casearia & - & Inga & Guapira & - \\
\hline & 一 & Serjania & - & Myrcia & Lantana & 一 \\
\hline
\end{tabular}


and Maia \& Carvalho-Fernandes, 2016). However, we do not corroborate the results found in other studies where the Asteraceae family is recorded as richier in insect galls (Maia \& Souza, 2013; Santos \& Ribeiro, 2015; UrsoGuimarães et al., 2016). Regarding the genera of host plants, the results confirm other studies where Croton is considered a super host, accumulating nine different galls morphotypes (Teixeira \& Isaias, 2013). These results can be explained by the fact that the species Allophylus edulis and Croton sp. presented a high richness of insect galls. Some host plants have few associated insect species (Hawkins \& Compton, 1992). In contrast, other plants support a high level of richness of galling insects, such as the species Baccharis pseudomyriocephala Teodoro (Asteraceae) (Araújo et al., 2003), Guapira opposita (Vell.) Reitz. (Nyctaginaceae) (Maia et al., 2008) and Mikania glomerata Spreng. (Asteraceae) (Maia \& Proença, 2016) in the Neotropical Region. The presence of these plants, called "super-hosts" (Veldtman \& McGeoch, 2003), can cause a dramatic increase in the local accumulation of galling insect species (Carneiro et al., 2009).

Leaf galls predominated. This is observed in all other Brazilian biomes and all biogeographical regions, probably because leaves represent an abundant and frequently renewable resource, with undifferentiated meristematic cells that are essential to gall growth (Maia, 2011). Green and brown were the predominant colors. These colors are usually mentioned in Brazilian inventories (Maia et al., 2014). The majority of the galls were glabrous and one-chambered as in all other Brazilian galls inventories, excepting by Delfinópolis, where hairy galls were more frequent than glabrous (54\% and $46 \%$, respectively) (Urso-Guimarães et al., 2003).

Cecidomyiidae (Diptera) was the most frequent galling insect, followed by Hemiptera and Lepidoptera. Cecidomyiidae are the most speciose and frequent galling insects in all zoogeographic regions (Gagné \& Jaschhof, 2014). Hemiptera and Lepidoptera are also important gallers. In the Neotropical region, they are the second and third most frequent galling insects (Maia, 2006). Coleoptera is the fourth (Maia, 2012), but they were not found in the searched area.

Hymenoptera are the most important natural enemies of Cecidomyiidae (Diptera). They are frequently found in galls induced by these midges mostly acting as parasitoids, and in some cases as phytophagous able to modify the structure and morphology of the gall (Maia \& Azevedo, 2009).

\section{CONCLUSIONS}

The Floresta da Cicuta was the third area in richness of insect galls compared to the other areas of Semidecidual Seasonal Forest physiognomy. The present study registered the Euphorbiaceae and Sapindaceae as the plant families with the highest morphotypes of galls in the studied physiognomy. The distribution of the galls in the plant organs followed the pattern already known in other studies, with predominance of leaf galls and the stems followed by buds. Most of the galls presented the following morphological characteristics: same coloration of the occurrence organ, a single internal chamber, and glabrous, also predominant in other studies. Three orders of galling insects were found: Diptera (Cecidomyiidae), Lepidoptera and Hemiptera, with clear predominance of Cecidomyiidae.

\section{ACKNOWLEDGEMENTS}

We would like to thank Valéria Cid Maia for a careful first reading of the manuscript and identification of the gall inducers, and the whole team at the ICMBIO - Floresta da Cicuta (Sandro Leonardo Alves, Glaucia Alves Viana de Oliveira, Vanessa Martins de Nazareth, José Henrique de Oliveira) for support and readiness during the execution of the study. We thank the anonymous reviewers for suggestions on earlier versions of the manuscript.

\section{REFERENCES}

Almada, E.D. \& Fernandes, G.W. 2011. Insetos indutores de galhas em florestas de terra firme e em reflorestamentos com espécies nativas na Amazônia Oriental, Pará. Brasil. Boletim Museu Paraense Emilio Goeldi, 6: 163-196.

APG III. 2009. An update of the Angiosperm Phylogeny Group classification for the orders and families of flowering plants: APG III. Botanical Journal of the Linnean Society, 161: 105-121.

Araújo, A.P.A.; Carneiro M.A.A. \& Fernandes G.W. 2003. Efeitos do sexo, do vigor e do tamanho da planta hospedeira sobre a distribuição de insetos indutores de galhas em Baccharis pseudomyriocephala Teodoro (Asteraceae). Revista Brasileira de Entomologia, 47: 483-490.

Araújo, W.S.; Santos, B.B. \& Gomes-Klein, V.L. 2011. Insect galls from Serra dos Pireneus, G0, Brazil. Biota Neotropica, 11(2): 357-364.

Bregonci, J.M.; Polycarpo, P.V. \& Maia, V.C. 2010. Galhas de insetos do Parque Estadual Paulo César Vinha (Guarapari, ES, Brasil). Biota Neotropica, 10: 227-238.

Bronner, R. 1992. The role of nutritive cells in the nutrition of cynipids and cecidomyiids, In: Shorthouse, J.D. \& Rohfritsch, 0. (Eds.). Biology of insect induced galls. New York, Oxford University Press. p. 118-140.

Carneiro, M.A.A.; Borges, R.A.X.; Araújo, A.P.A. \& Fernandes, G.W. 2009. Insetos indutores de galhas da porção sul da Cadeia do Espinhaço, MG. Revista Brasileira de Entomologia, 53: 570-592.

Carvalho, L.L.G.; Santos, R.N.S. \& Barbosa, J.B. 2015. Ocorrência de galhas entomógenas em plantas do Parque Florestal dos Pioneiros. Maringá, PR, Brasil. Revista UNINGÁ, 23(1): 21-23.

Carvalho-Fernandes, S.P.; Almeida-Cortez, J.S. \& Ferreira, A.L.N. 2012. Riqueza de galhas entomógenas em áreas antropizadas e preservadas de Caatinga. Revista Árvore, 2: 269-277.

Carvalho-Fernandes, S.P.; Ascendino, S.; Maia, V.C. \& Couri, M.S. 2016. Diversity of insect galls associated with coastal shrub vegetation in Rio de Janeiro, Brazil. Anais da Academia Brasileira de Ciências, 88(3): 1407-1418.

Coelho, M.S.; Almada, E.D.; Fernandes, G.W.; Carneiro, M.A.A.; Santos, R.M. \& Sanchez-Azofeifa, A. 2009. Gall inducing arthropods from a seasonally dry tropical Forest in Serra do Cipó, Brazil. Revista Brasileira de Entomologia, 53: 404-414.

Costa, A. 2004. Volta Redonda ontem e hoje. Volta Redonda,. Editor Jader Costa, 1 CD-ROM. (Edição comemorativa 50 anos). 
Fernandes, G.E.; Carneiro, M.A.A.; Lara, A.C.F.; Allain, L.R.; Andrade, G.l.; Julião, G.R.; Reis, T.R. \& Silva, I.M. 1996. Galling insects on neotropical species of Baccharis (Asteraceae). Tropical Zoology, 9: 315-332.

Fernandes, G.W. \& Price, P.W. 1988. Biogeographical gradients in galling species richness: tests of hypotheses. Oecologia, 76: 161-167.

Fernandes, G.W.; Araújo, L.M.; Carneiro, M.A.A.; Cornelissen, T.G.; BarcelosGreco, M.C.; Lara, A.C.F. \& Ribeiro, S.P. 1997a. Padrões de riqueza de insetos galhadores em gradientes altitudinais na Serra do Cipó, Minas Gerais. In: Leite, L.L. \& Saito, C.H. (Orgs.). Contribuição ao conhecimento ecológico. Brasília, Universidade de Brasília. (30 Congresso de Ecologia do Brasil)

Fernandes, G.W.; Araújo, R.C.; Araújo, S.C.; Lombardi, J.A.; Paula, A.S.; Loyola Jr., R. \& Cornelissen, T.G. 1997b. Insect-galls from savanna and rocky fi elds of the Jequitinhonha valley, Minas Gerais, Brazil. Naturalia, 22: 221-244.

Fernandes, G.W.A.; Tameirão-Neto, E. \& Martins, R.G. 1988. Ocorrência e caracterização de galhas entomógenas na vegetação do Campus Pampulha da Universidade Federal de Minas Gerais. Revista Brasileira de Zoologia, 5(1): 11-29.

Flora do Brasil. 2020. [em construção]. Jardim Botânico do Rio de Janeiro. Available at: http://floradobrasil.jbrj.gov.br. Access in: 18/06/2016.

Gagné, R. 1994. The Gall Midges of the Neotropical Region. Ithaca, Cornell University Press.

Gagné, R.J. \& Jaschhof, M. 2014. A Catalog of the Cecidomyiidae (Diptera) of the World. 3.ed. Digital Version 2.

Hawkins, B.A. \& Compton, S.G. 1992. African fig wasp communities: under saturation and latitudinal gradients in species richness. Journal of Animal Ecology, 61: 361-372.

Houard, C. 1933. Les Zoocécidies des plantes de l'Amérique du Sud e de I'Amérique Central. Paris, Hermann et Cie. 519 p.

Instituto Brasileiro de Geografia e Estatística (IBGE). 1992. Manual técnico da vegetação brasileira. Rio de Janeiro, IBGE. 166 p. (Manuais técnicos em geociências)

Isaias, R.M.S.; Carneiro, R.G.S.; Oliveira, D.C. \& Santos, J.C. 2013. Illustrated and annotated checklist of Brazilian Gall morphotypes. Neotropical Entomology, 42: 230-239.

Maia, V.C. 1993. Considerações sobre Stephomyia Tavares (Diptera, (ecidomyidae, Asphondyliidi) com descrição de quatro espécies novas associadas com Eugenia L. e Neomithranthes obscura (DC.) Legr. (Myrtaceae). Revista Brasileira de Zoologia, 10(3):521-530.

Maia, V.C. 1996a. Cordiamyia globosa gen. n. e sp. n. (Diptera, Cecidomyiidae, Cecidomyiidi) associado com Cordia verbenacea DC. (Boraginaceae) no Brasil. Revista Brasileira de Zoologia, 13(3): 579-583.

Maia, V.C. 1996b. Clusiamyia nitida gen. n. e sp. n. (Diptera, Cecidomyiidae, Cecidomyiidi) associada com Clusia lanceolata Camb. (Clusiaceae) no Brasil. Revista Brasileira de Zoologia, 13(4): 829-832.

Maia, V.C. 2001. The gall midges (Diptera, Cecidomyiidae) from three restingas of Rio de Janeiro State, Brazil. Revista Brasileira de Zoologia, 18: 583-629.

Maia, V.C. 2006. Galls of Hemiptera, Lepidoptera and Thysanoptera from central and South America. Publicações Avulsas do Museu Nacional, 110: $1-22$.

Maia, V.C. 2011. Characterization of insect galls, gall makers, and associated fauna of Platô Bacaba (Porto de Trombetas, Pará, Brazil). Biota Neotropica, 11:37-53.

Maia, V.C. 2012. Coleopterous galls from the Neotropical region. Papéis Avulsos de Zoologia, 52(15): 175-184.

Maia, V.C. 2014. Insect galls of Itamonte (Minas Gerais, Brazil): characterization and occurrence. Biota Neotropica, 14: 1-17.

Maia, V.C. \& Azevedo, M.A.P. 2009. Micro-himenópteros associados com galhas de Cecidomyiidae (Diptera) em Restingas do Estado do Rio de Janeiro (Brasil). Biota Neotropica, 9: 151-164.
Maia, V.C. \& Carvalho-Fernandes, S.P. 2016. Insect galls of a protected remnant of the Atlantic Forest tableland from Rio de Janeiro State (Brazil). Revista Brasileira de Entomologia, 60: 40-56.

Maia, V.C. \& Fernandes, G.W. 2004. Insect galls from Serra de São José (Tiradentes, MG, Brazil). Brazilian Journal of Biology, 64(3), 423-445.

Maia, V.C. \& Monteiro, R.F. 1999. Espécies cecidógenas (Diptera, (ecidomyiidae) e parasitóides (Hymenoptera) associadas a Guapira opposita (Vell.) Reitz. (Nyctaginaceae) na Restinga da Barra de Maricá, Rio de Janeiro. Revista Brasileira de Zoologia, 16(2): 483-487.

Maia, V.C. \& Oliveira, J.C. 2010. Galhas de insetos da Reserva Biológica Estadual da Praia do Sul (llha Grande, Angra dos Reis, RJ). Biota Neotropica, 10: 227-238.

Maia, V.C. \& Proença, B. 2016. Insect galls on Mikania glomerata (Asteraceae) in an area of Atlantic Forest in Viçosa (Minas Gerais, Brazil). Check List, 12: 1988-2026.

Maia, V.C. \& Silva, L.0. 2016. Insect galls of Restinga de Marambaia (Barra de Guaratiba, Rio de Janeiro, RJ). Brazilian Journal of Biology, 76(3): 787-795.

Maia, V.C. \& Souza, M.C. 2013. Insect galls of the xeric vegetation of Illha do Cabo Frio (Arraial do Cabo, RJ, Brazil). Biota Neotropica, 13: 278-288.

Maia, V.C. \& Tavares, M.T. 2000. Cordiamyia globosa Maia (Diptera, (ecidomyiidae), flutuação populacional e parasitóides (Hymenoptera) associados. Revista Brasileira de Zoologia, 17(3): 589-593.

Maia, V.C.; Cardoso, L.J.T. \& Braga, J.M.A. 2014. Insect galls from Atlantic Forest areas of Santa Teresa, Espírito Santo, Brazil: characterization and occurrence. Boletim do MBML, 33: 47-129.

Maia, V.C.; Fernandes, G.W.; Magalhães, H. \& Santos, J.C. 2010. Two new species of Lopesia Rübsaamen (Diptera, Cecidomyiidae) associated with Mimosa hostilis (Mimosaceae) in Brazil. Revista Brasileira de Entomologia, 54(4): 578-583.

Maia, V.C.; Magenta, M.A.G. \& Martins, S.E. 2008. Ocorrência e caracterização de galhas de insetos em áreas de restinga de Bertioga (São Paulo, Brasil). Biota Neotropica, 8: 167-197.

Mani, M.S. 1964. The ecology of plant Galls. The Hague, Dr. Junk. xii + 434p.

Mendonça, M.S.; Toma, T.S.P. \& Silva, J.S. 2014. Galls and Galling Arthropods of Southern Brazil. In: Fernandes, G.W. \& Santos, J.C. (Eds.). Neotropical Insect Galls. New York, Springer. cap. 14, p. 221-256.

Monteiro, R.F.; Oda, R.A.M.; Narahara, K.L. \& Constantino, P.A.L. 2004. Galhas: Diversidade, Especificidade e Distribuição. In: Rocha, C.F.D.; Esteves, F.A. \& Scarano, F.R. (Eds.). Pesquisa de longa duração na Restinga de Jurubatiba: ecologia, história natural e conservação. São Carlos, RiMa Editora. p. 127-141.

Nogueira, R.M.; Costa, E.C.; Carvalho-Fernandes, S.P. \& Silva, J.S. 2016. Insect galls from Serra Geral, Caetité, BA, Brazil. Biota Neotropica, 16: e20150035.

Oliveira, J.C. \& Maia, V.C. 2005. Ocorrência e caracterização de galhas de insetos na restinga de Grumari (Rio de Janeiro, RJ, Brasil). Arquivos do Museu Nacional, 63: 669-676.

Rodrigues, A.R.; Maia, V.C. \& Couri, M.S. 2014. Insect galls of restinga areas of Ilha da Marambaia, Rio de Janeiro, Brazil. Revista Brasileira de Entomologia, 58: 173-197.

Rübsaamen, E.H. 1905. Beitrage zur Kenntnis aussereuropaischer Zoocecidien. II. Beitrag: Gallen aus Brasilien und Peru. Marcellia, 4: 65-85; 115-138.

Saito, V.S. \& Urso-Guimarães, M.V. 2012. Characterization of galls, insect galls and associated fauna of Ecological Station of Jataí (Luiz Antônio, SP). Biota Neotropica, 12: 99-107.

Santos, B.B.; Ferreira, H.D. \& Araújo, W.S. 2010. Ocorrência e caracterização de galhas entomógenas em uma área de Floresta Estacional Semidecídua em Goiânia, Goiás, Brasil. Acta Botanica Brasilica, 24(1): 243-249.

Santos, B.B.; Ribeiro, B.A.; Silva, T.M. \& Araújo, W.S. 2012. Galhas de insetos em uma área de cerrado sentido restrito na região semi-urbana de Caldas 
Novas (Goiás, Brasil). Revista Brasileira de Biociências, Porto Alegre, 10(4): 439-445.

Santos, P.O. \& Ribeiro, J.E.L.S. 2015. Ocorrência e caracterização de galhas em fragmento de Floresta Estacional Semidecidual em Telêmaco Borba, Paraná, Brasil. Semina: Ciências Biológicas e da Saúde, Londrina, 36(2): $15-24$.

Silva, M.H.M.; Costa-Filho, L.0.; Oliveira, A.F.M. \& Almeida-Cortez, J.S. 2011. Ocorrência de Galhas em espécies de Croton no Parque Nacional Vale do Catimbau (PE). Revista Brasileira de Geografia Física, 3: 510-519.

Tavares, J.S. 1909. Contributio prima ad cognitionem cecidologiae braziliae. Brotéria, Série Zoológica, 8: 5-28.

Tavares, J.S. 1915. As cecídias das plantas do gênero Styrax do Brazil. Brotéria, Série Zoológica, 13: 145-160, pl. Vl.

Tavares, J.S. 1922. Cecidologia Brazileira. As restantes famílias. Brotéria, Série Zoológica, 20: 5-48.

Tavares, J.S. 1925. Nova contribuição para o conhecimento da Cecidologia Brazileira. Brotéria, Série Zoológica, 22: 5-55.

Teixeira, C.T. \& Isaias, R.M.S. 2013. Respostas teciduais convergentes e divergentes em galhas de Cecidomyiidae na super-hospedeira Croton floribundus. In: Congresso Nacional de Botânica, 64 . Anais. Belo Horizonte, MG. Sociedade de Botânica do Brasil.
Toma, T.S.P. \& Maia, V.C. 2012. Representatividade do gênero Clinodiplosis Kieffer (Diptera, Cecidomyiidae) no Brasil. Papéis Avulsos de Zoologia, 52: 223-231.

Toma, T.S.P. \& Mendonça, M.S. 2013. Gall-inducing insects of an Araucaria Forest in southern Brazil. Revista Brasileira de Entomologia, 57: 225-233.

Urso-Guimarães, M.V. \& Scarelli-Santos, C. 2006. Galls and gall makers in plants from the Pé-de-Gigante Cerrado Reserve, Santa Rita do Passa Quatro, SP, Brazil. Brazilian Journal Biology, 66: 357-369.

Urso-Guimarães, M.V.; Castello, A.C.D.; Kataokaa, E.Y. \& Koch, I. 2016 Characterization of entomogen galls from Mato Grosso do Sul, Brazil. Revista Brasileira de Entomologia, 61: 25-42.

Urso-Guimarães, M.V.; Scarelli-Santos, C. \& Bonifácio-Silva, A.C. 2003. Occurrence and characterization of entomogen galls in plants from natural vegetation areas in Delfinópolis, MG, Brazil. Brazilian Journal of Biology, 63: 705-715.

Veldtman, R. \& McGeoch, M.A. 2003. Gall forming insect species richness along a non-scleromorphic vegetation rainfall gradient in South Africa: The importance of plant community composition. Austral Ecology, 28: $1-13$. 